\title{
AZ IFRS 9 SZERINTI ÉRTÉKVESZTÉSKÉPZÉS HATÁSA AZ EURÓPAI BANKOK MEGÍTÉLÉSÉRE
}

\author{
Szücs Tamás - Márkus Gábor
}

A pénzügyi válság után a nemzetközi számvitelt alakító szabályrendszerek a korábbi szabályok megújítására kényszerültek annak érdekében, hogy a pénzügyi zavarok előre jelezhetőek legyenek a jövőben. 2018. január 1-jével az IFRS 9 standard új elvek mentén szabályozta a pénzügyi instrumentumok besorolását, értékelését és az értékvesztés elszámolását. Tanulmányunkban azt vizsgáltuk, hogy az IFRS 9 által érintett beszámolóadatok közül melyek azok, amelyek a pénzintézetek árfolyamát jelentősen befolyásolták. Eredményeink alapján a piacot leginkább a pénzügyi instrumentumok és az értékvesztés állománya befolyásolta, sokkal nagyobb mértékben, mint ugyanezeknek az adatoknak az időbeli változása.

JEL-kódok: G21, M41

Kulcsszavak: IFRS 9, pénzügyi instrumentumok, értékvesztés, részvényárfolyam

\section{BEVEZETÉS}

Az 1970-es évektől kezdve, különösen az elmúlt évtizedben, a világ pénzügyi piacai óriási fejlődésen mentek keresztül. A pénzügyi rendszer globalizációjából eredően az egyes pénzügyi tranzakciók elszámolását nem lehet lesarkítani egy adott ország saját számviteli szabályozása szerint. A hagyományos tranzakciók mellett újfajta pénzügyi instrumentumok jelentek meg, amelyeket nemcsak pénzintézetek, hanem más vállalkozások is - különböző célokkal - széles körben használnak. A megfelelő számviteli standardok értékelési kritériumai implicit módon nem képesek a cég piaci értékét meghatározni. A hagyományos számviteli nyilvántartások az egyes vagyontárgyak értékét a múltbeli, a vásárláskor kifizetett ellenérték alapján állapítják meg. A múltbeli (bekerülési) érték alkalmazását sokszor, sokan kritizálták, erről összefoglaló tanulmányok is születtek (Georgiou-Jack, 2011). A probléma megoldására fejlődött ki a valós értékelés tech-

1 Szücs Tamás adjunktus, Közgazdaságtudományi Kar, Pécsi Tudományegyetem. E-mail: szucs. tamas@ktk.pte.hu.

Márkus Gábor adjunktus, Közgazdaságtudományi Kar, Pécsi Tudományegyetem. E-mail: markus.gabor@ktk.pte.hu. 
nikája. A valós érték a gyakorlatban a vagyontárgyak jelenlegi értékét részesíti előnyben, amely az elérhető szabályozott, likvid piacon kialakult árakon alapul. A likvid piacon kellő számú vevő és eladó áll kapcsolatban egymással, így hatékony árazás alakulhat ki.

A vállalat működése során többféle kockázati forrás léphet fel, amely a jövőbeli működést alapvetően befolyásolja. A kockázatok tekintetében célszerü megkülönböztetni gazdasági, pénzügyi, politikai stb. kockázatot. A pénzügyi kockázat az árfolyam- és kamatkockázatot foglalja magában. A hatékony kockázatmenedzsmentnek elengedhetetlen feltétele, hogy a pénzügyi instrumentumok értéke, valamint az azokból eredő hasznok és kockázatok ismertek legyenek.

A 2008. második felében kialakult világméretű pénzügyi válságra reagáltak a számviteli szabályalkotó testületek is. A Nemzetközi Számviteli Standardok Bizottsága (IASB) már 2008 novemberében megkezdte egy új standard kidolgozását azzal a céllal, hogy az alkalmasabbá váljon a gazdasági, pénzügyi válságok által generált problémák leküzdésére. Ezen túlmenően hatékonyabb prevenciós módszertan kidolgozása is a célok között szerepelt. Az IFRS 9 standard három témakört kívánt szabályozni:

1) a pénzügyi instrumentumok egyszerübb, hatékonyabb csoportosítását és értékelési mechanizmusát,

2) a prevenció legfontosabb eszközeként használt értékvesztés képzését, illetve

3) a fedezeti ügyleteket.

\section{AZ IAS 39 SZERINTI PÉNZÜGYI INSTRUMENTUMOK BESOROLÁSA ÉS AZ ÉRTÉKVESZTÉS}

Az IAS 39 - 2017. december 31-ig hatályban lévő - standard szerint a pénzügyi instrumentumokat négy csoportba sorolhattuk:

1) A kereskedelmi pénzügyi eszközök vagy kötelezettségek közé sorolt vagyonelemek valós értékének változásait közvetlenül az eredményben (nyereségként vagy veszteségként) kellett elszámolni, így ezek az értékváltozások közvetlenül befolyásolhatják a vállalat tárgyévi jövedelmezőségét.

2) A valós értéken értékelt pénzügyi instrumentumok másik csoportjába azok a pénzügyi eszközök tartoznak, amelyek esetében nem a kereskedelmi jelleg dominál, azonban birtokosuk nem is kívánja a lejáratukig megtartani őket, vagy egyáltalán nem rendelkeznek futamidővel - ezek az ún. értékesithető pénzügyi eszközök. A standard értékelési szabályainak megfelelően az ilyen eszközök kezdeti értékelésekor a bekerülési érték és a valós érték közötti kü- 
lönbözetet az eredményben kell elszámolni, ugyanakkor a későbbiekben az értékeléseket a saját tőkén belül elkülönítetten, átértékelési tartalékként (más néven egyéb átfogó jövedelemként - other comprehensive income, OCI) kellett megjeleníteni. Az így keletkező felértékelések tehát nem közvetlenül a tárgyévi eredményt, hanem a vállalat nettó eszközértékét (saját tőkéjét) módosítják. Az említett átértékelési tartalék természetesen nem véglegesen képezi a saját tőke részét, azt az eszköz kivezetésekor (például értékesítés esetén) az eredménybe kell átvezetni az IAS 39 standard szerint. Amennyiben az értékesíthető pénzügyi eszközök értékében olyan negatív változás következik be, amely a standardban rögzített, objektív módon bizonyítható, akkor a veszteséget az eredmény terhére, értékvesztésként kell elszámolni.

3) A harmadik értékelési kategória a lejáratig tartott pénzügyi instrumentumok, amelyek olyan meghatározott futamidővel és rögzített vagy meghatározható kifizetésekkel rendelkező eszközök, amelyeket a vállalkozás lejáratig kíván megtartani.

4) A negyedik csoport a saját jogon keletkeztetett követelések. Ezek a vállalkozás termékeinek és szolgáltatásainak értékesítésekor vagy kölcsön nyújtásakor keletkező követelések. Ezen instrumentumok esetében a vállalkozásnak nem célja a rövid távú értékesítés. Mind a lejáratig tartott instrumentumokat, mind a saját jogon megszerzett követeléseket amortizált bekerülési értéken kell értékelni.

A pénzügyi válság elején (2018. október) az IASB a krízis tompítása érdekében lehetővé tette a vállalkozások nem derivatív kereskedelmi és értékesíthető pénzügyi instrumentumainak az átsorolását. Fiechter (2011) európai bankok körében elvégzett elemzése szerint az érintett szervezetek egyharmada élt az átsorolás nyújtotta lehetőséggel. Az átsorolások eredményhatásai a vizsgált bankok jövedelmezőségét kedvező irányba módosították. Ez az óvatosság elvéhez közelebb álló eredmény bemutatásához vezetett, ami az elemzők körében kedvező fogadtatásra talált. Lim et al. (2012) azt vizsgálták, hogy a 2008-as átsorolások milyen irányba befolyásolták az elemzők előrejelző képességét. Megállapították, hogy jelentős mértékben csökkent az elörejelzések pontossága, azonban a hatások csak az adott évre vonatkoztak. Zhan (2013) 122 európai bank esetében azt vizsgálta, hogy az átsorolások milyen irányú változásokat indukáltak az adott hitelintézet likviditásában. Az átsorolással élő bankok esetében ennek negatív hatása volt a likviditásra. Ozili (2019) tanulmányában azt elemezte, hogy az IAS 39 standard által biztosított, a fentiekben bemutatott kategóriák közötti átsorolás milyen mértékben használható fel a jövedelmek kisimítására. A szerző előfeltevése az volt, hogy a bankok az értékvesztést használják fel a jövedelmeik simítására. Az elvégzett elemzés során megállapította, hogy a 2005-2013 közötti időszakban az európai bankok körében nem az értékvesztés volt az eszköze a jövedelmek kiegyensúlyozásának, továb- 
bá, hogy az IAS 39 által elöírt közzétételi kötelezettségek nagymértékben javították a hitelezési veszteségek becslését, a beszámolók informativitását. Paananen, Renders és Shima (2011) azt vizsgálta, hogy az IAS 39 szerint elvégzett átsorolásoknak voltak-e tőkepiaci következményei. A szerzők szerint az átsorolásoknak két lehetséges mozgatórugója volt, nevezetesen a szolvencia és a pénzügyi piacoknak való kitettség. Az első a minimálishoz közeli tőkemegfelelési mutatókkal rendelkező bankok esetében fordult elő, míg a második a nagyobb valós értékelés kitettségü szereplők esetében növelte az átsorolás valószínüségét.

Az IAS 39 standard a hagyományos számviteli logikát követte, amely szerint csak akkor lehet egy eseményt rögzíteni, ha azt megfelelő bizonyítékokkal, bizonylatokkal alá lehet támasztani. A standardban alkalmazott értékvesztési modell („felmerült veszteség modell”) szigorúan objektív bizonyítékok alapján engedte elszámolni az adott pénzügyi instrumentum esetében a felmerült értékvesztést. Alapvetően ez egy „adóhivatal-barát” megoldás, hiszen már megtörtént, megfelelően dokumentált események bemutatását jelenti, illetve így vált ismertté a befektetők számára.

A 2008-as pénzügyi válság megvilágította ennek árnyoldalát. Az értékvesztés csak a már felmerült veszteségeket engedte elszámolni, így a modell alkalmazása során a pénzügyi eszközökkel kapcsolatos hitelezési veszteségeket csak utólag mutatták ki, így ez a megoldás az érintettek számára túl későn jelent meg a könyvekben.

Fontos kihangsúlyozni, hogy a beszámolót elkészítők nem vehették figyelembe a mérleg fordulónapját követően bekövetkező jövőbeli események lehetséges hatásait, még akkor sem, ha azok - akár nagy valószínűséggel - előre láthatóak voltak. A felmerült veszteség modell keretei között a bankmenedzsment csak azokat az értékvesztéseket számolhatta el a veszteséget jelentő hitelesemény előtt, amelyek bekövetkezési valószínűsége (PD) megközelítette a 100\%-ot. A várható veszteségek aktuális értékének kiszámításához az eredeti effektív kamatlábat kell alkalmazni diszkontrátaként. Az 1. ábra rávilágít arra, hogy a várható veszteségek lehetséges becsléseinek folytonosságából a felmerült veszteségek a legalacsonyabb értékhatárt jelentik. A felmerült veszteség modell ellentétes gondolkodású a felügyeleti szabályokhoz (Bázel I-III). képest. A bankoknak az IAS 39 keretei között lényegesen nagyobb lehetőségük volt a jövedelemsimításra, mint a bázeli szabályok szerinti jövőbe mutató veszteségkezeléssel (Gerhardt-Novotny-Farkas, 2011). 


\section{1. ábra}

\section{Várható veszteség}

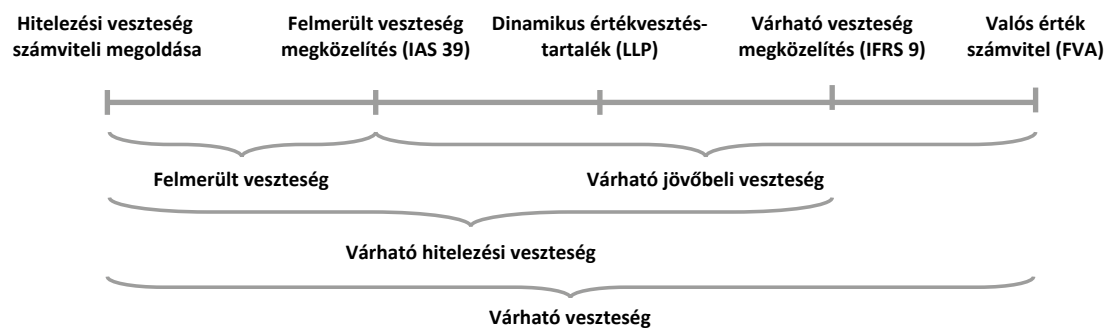

Forrás: Gebhardt-Novotny-Farkas (2011) alapján saját szerkesztés

Az IAS 39 ellen a legföbb kritika a bonyolultsága és alkalmazási nehézségei voltak, amelyek a pénzügyi kimutatások átláthatóságának a rovására mennek (Fiechter, 2011; Paananen et al., 2012; Laux-Lenz, 2010; Laux, 2012). Gerhardt-NovotnyFarkas (2011) és O’Hanlon (2013) is hangsúlyozza: a fordulónapi értékelés nem teszi lehetővé, hogy a jövőbeli veszteségekre időben reagáljanak, így késői felismeréshez vezet. A felmerült veszteség modell hozzájárult a prociklikussághoz azáltal, hogy a bankokat nagyobb értékvesztési tartalék képzésére „ösztönzi” a recessziós időszak alatt (El Sood, 2012; Beatty-Liao, 2011)

\section{AZ IFRS 9}

Az új IFRS 9 a korábbi szabályokat alapvetően rendezte át a pénzügyi instrumentumok elszámolása területén. Az új standard megalkotását több körülmény is motiválta. Egyrészt a globális számviteli elvek napjainkban is zajló közelítése a különböző számviteli rendszerekhez, másrészt a pénzügyi termékek elszámolásának egyszerüsítése; ezen túl a válság ideje alatt az IAS 39-cel szemben felerősödő kritikára adott megnyugtató válaszok is a célok között szerepeltek. Az IFRS 9 egy átfogó, igen nagyra törő projekt keretében több fázisra bontva írta át az IAS 39-et: megváltoztak a besorolási kategóriák, ebből következően az értékelésük is változott, továbbá megváltozott az értékvesztésük kiszámításának logikája.

\subsection{Az IFRS 9 standard szerinti csoportosítás}

A látványosabb, bár szakmai szempontból kisebb jelentőségű változás a pénzügyi instrumentumok besorolásában következett be. Az IAS 39 a tartási célhoz kötötten határozta meg az instrumentumok besorolását, „beszédes” elnevezéseik is ehhez igazodtak. Az IFRS 9 ezzel szemben már az értékelési módszert helyezte 
előtérbe, és eszerint alakultak a kategóriamegnevezések is. Ezt a folyamatot az 1. táblázat foglalja össze.

\section{1. táblázat}

Pénzügyi instrumentumok besorolásának változása

\begin{tabular}{lccc}
\hline IFRS9 & $\begin{array}{c}\text { Eredménnyel } \\
\text { szemben }(F V T P L) \\
\text { valós értéken értékelt }\end{array}$ & $\begin{array}{c}\text { OCI-val szemben } \\
(F V T O C I)\end{array}$ & $\begin{array}{c}\text { Amortizált } \\
\text { bekerülési értéken } \\
\text { értékelt }(A C)\end{array}$ \\
\hline $\begin{array}{l}\text { IAS39 } \\
\text { Kereskedési célú }(H F T)\end{array}$ & $\mathrm{x}$ & $\mathrm{x}$ \\
$\begin{array}{l}\text { Saját jogon } \\
\text { keletkeztetett }\end{array}$ & & megszünt, át kell sorolni & \\
$\begin{array}{l}\text { Lejáratig tartott } \\
(H T M) \text { eszközök }\end{array}$ & & & $\mathrm{x}$ \\
$\begin{array}{l}\text { Lejáratig tartott } \\
\text { (HTM) kötelezettségek }\end{array}$ & & $\mathrm{x}$ & $\mathrm{x}$ \\
Értékesíthető $($ AFS $)$ & $\mathrm{x}$ & & \\
\hline
\end{tabular}

Forrás: saját szerkesztés

Az IFRS 9-ben megszűnnek az IAS 39 standard által alkalmazott „értékesíthető” és „lejáratig tartott” besorolási kategóriák (a lejárat előtti értékesítés következményeivel kapcsolatos szabályokkal együtt). Az új standard szerint a következő értékelési kategóriákat lehet alkalmazni:

1) Amortizált bekerülési értéken értékelt pénzügyi instrumentumok (AC) esetén a gazdálkodó célja pénzáramok (tőke és kamat) beszedése.

2) Az egyéb átfogó eredménnyel szemben valós értéken értékelt pénzügyi instrumentumok (FVTOCI) esetében a pénzáramok realizálása mellett értékesítési cél is megjelenhet.

3) Az eredménnyel szemben valós értéken értékelt pénzügyi instrumentumok (FVTPL) az „egyéb” funkcióját töltik be, tehát ha nem amortizált bekerülési értéken vagy az egyéb átfogó jövedelemmel szemben értékelt kategóriába került besorolásra, akkor itt kell az instrumentumot kimutatni.

A régi standard szerinti értékesíthető pénzügyi instrumentumok és az új szerinti, egyéb átfogó jövedelemmel szemben értékelt pénzügyi instrumentumok első ránézésre hasonló értékelési kategóriának tűnhetnek. Ha azonban a szabályozás besorolási kritériumait összehasonlítjuk, akkor már nem ennyire egyértelmű a döntés. Az IFRS 9 szigorúan előírja a szerződéses cash flow realizálását (tőke és kamat), míg az IAS 39 csak képességről és szándékról rendelkezett, így a gazdálkodóknak az 2018. január 1-jei újracsoportosításnál az értékesíthető pénzügyi instrumentumok egy részét az amortizált bekerülési értéken értékelt kategóriába kell átsorolniuk. 


\subsection{Az IFRS 9 standard szerinti értékvesztés}

Az új IFRS 9 standard a bankoktól megköveteli, hogy szélesebb információs bázist alakítsanak ki a hitelezési veszteségek meghatározásához. A beszámolót készítő pénzintézeteknek a múltbeli tapasztalatokból, a jelenlegi feltételekből és a jövőbeli észszerü, várható előrejelzésekből származó információkat kell összegezni a hitelezési veszteségek méréséhez. Az új szabályrendszer az értékvesztés meghatározását nem a kedvezőtlen hitelesemény bekövetkezéséhez rendeli hozzá, hanem folyamatosan figyelni kell a várható hitelezési veszteség (expected credit loss - ECL) alakulását, ami preventív jelleggel lehetővé teszi, hogy az IAS 39 szabályozásával szemben a problémákat időben fel lehessen ismerni.

Az új szabványok a hitelekkel kapcsolatban különböző intézkedéseket írnak elő attól függően, hogy milyen kockázatokat azonosítottak. Eszerint három különböző „kosárba” sorolhatók a folyósított hitelek aszerint, hogy mekkora a fizetésképtelenségi kockázatuk.

1. kategória: Az amortizált bekerülési értéken nyilvántartott eszközöknél már a nyilvántartásba vételkor kötelező a 12 hónapon belül várható veszteségekre elegendő értékvesztést képezni, és ennek összege nem lehet nulla. A régi IAS 39 standard nem tartalmaz ilyen előírást.

2. kategória: Azon instrumentumoknál, ahol jelentősen növekedett a hitelkockázat mértéke, a teljes élettartamra vonatkozó várható hitelezési veszteséget kell meghatározni egyedi, illetve portfóliószinten. Az IAS 39-ben ilyen rendelkezés nem szerepelt.

3. kategória: Egy adott pénzügyi eszköz már a kezdeti megjelenítésnél, nyilvántartásba vételkor értékvesztett (így vásároltuk), tehát nemteljesítő pénzügyi eszköz. A nemteljesítő pénzügyi eszközök esetében az instrumentum könyv szerinti értéke (nettó érték) alapján történik a hátralévő futamidőre vonatkozó értékvesztés elszámolása.

\section{2. táblázat}

Várható hitelezési veszteség elszámolása

\begin{tabular}{lcc}
\hline $\begin{array}{l}\text { IFRS 9 szerinti } \\
\text { kategória }\end{array}$ & Hitel minősítése & $\begin{array}{c}\text { Várható hitelezési } \\
\text { veszteség (ECL) }\end{array}$ \\
\hline $\begin{array}{l}\text { 1. kategória } \\
\text { 2. kategória }\end{array}$ & $\begin{array}{c}\text { Teljesítő hitel } \\
\text { Alulteljesítő hitel }\end{array}$ & $\begin{array}{c}\text { Teljes élettartamra } \\
\text { várható veszteség }\end{array}$ \\
3. kategória & $\begin{array}{c}\text { Nemteljesítő hitel, } \\
\text { értékvesztett }\end{array}$ & \\
\hline
\end{tabular}

Forrás: (IFRS 9) alapján saját szerkesztés 
A hitelezési kockázat változásának mértéke az alapja az értékvesztés számításának (IFRS 9):

- ha az adott pénzügyi eszköz hitelezési kockázata a kezdeti megjelenítése óta nem nőtt meg jelentősen, akkor 12 havi várható hitelezési veszteségekkel kell az eszköz kapcsán számolni;

- ha az adott pénzügyi eszközre vonatkozó hitelezési kockázat jelentősen megnőtt a bekerülése óta vagy az előző értékelési időszakhoz képest, akkor az eszköz teljes élettartama alatt várható hitelezési veszteségeket kell figyelembe venni az értékvesztése meghatározása során.

Normál müködés közben a folyósított hitelek először az 1. kosárba kerülnek. Az adott hitel átsorolására akkor kerül sor, ha az ügyfélnek - az elöre meghatározott indikátorok alapján - romlik a hitelminősége, ha a jelek arra utalnak, hogy a bank által kidolgozott elörejelzési rendszer szerint a negatív hitelesemény bekövetkezésének valószínűsége növekedett. Emiatt az IFRS 9 standard szerint át kell sorolni a 2. kosárba mint alulteljesítő hitelt. Azok a hitelek, amelyek a banknak ténylegesen veszteségeket okoznak, a 3. kosárba sorolandók.

A standard 2018. január 1-jei bevezetésekor a gazdálkodóknak a 2017. évi beszámolójukat újra kellett számolni az új szabályok szerint. Ez egyrészt azt jelentette, hogy a pénzügyi instrumentumokat át kellett sorolni az új csoportosítás szerint, illetve az értékvesztést a megváltozott modell alapján az új értékre kellett átállítani. Mindez - természetesen - hatással van a bank mérlegföösszegére, illetve a pénzügyi eszközök és kötelezettségek minőségének megítélésére. Mivel az új értékvesztési szabályok szigorúbbak a korábbinál, így minden előzetes szakmai várakozás az értékvesztések növekedését és a mérlegföösszegek csökkenését jósolta. Nagyon szűk irodalom elemzi a banki értékvesztésképzés hatását az adott hitelintézet tőzsdei árfolyamának alakulására. Beaver et al. (1989) tanulmányukban egy olyan modellt mutattak be, amely a bankok közönséges részvényeinek piaci és könyv szerinti értéke közötti kapcsolatot vizsgálta annak a fényében, hogy a beszámolók kiegészítő információi mennyiben befolyásolják a két érték közötti különbséget. A modellezés során arra a következtetésre jutottak, hogy az adott bank hitelportfóliójával kapcsolatos, kiegészítő információk szignifikáns hatást fejtenek ki. Eredményeik alapján negatív kapcsolat állapítható meg a nemteljesítő hitelek arányának változása és a részvényár között. Az elemzésükben az értékvesztés képzése pozitív üzenetként jelenik meg a piaci szereplők számára, amit az óvatos gazdálkodás jeleként értelmeznek. Achmed et al. (1999) kutatásai arra irányultak, hogy kapcsolatot találjanak a töke- és jövedelemmenedzsment, valamint az értékvesztésképzés között. A 113 bank körében elvégzett elemzés eredménye szerint a megképzett értékvesztés negatívan hat a jövőbeli jövedelmezőség alakulására és a jelenlegi tőzsdei árfolyamokra is. 
Onali és Ginesti (2015) vizsgálódása arra irányult, hogy az értékvesztésre vonatkozó nemzetközi számviteli standardok megváltoztatása megfelelő „gyógymód” lehet-e a befektetők bizalmának helyreállítására. A szerzők véleménye szerint az új IFRS 9 szabályok alapján megképzett értékvesztés több okból is indukálhat változást a részvényárfolyamban. Állításuk szerint korrigálja a bankok időzítési lehetőségeit a pénzügyi instrumentumok értékvesztésének elszámolásra. Az árfolyamok pozitívan reagálhatnak, ha befektetők úgy ítélik meg, hogy a beszámolókban bemutatott értékvesztéseket időben elszámolták, amivel növelik az adott beszámoló megbízhatóságába vetett hitet az adott bank hitelállományának minőségére vonatkozóan. A 17 országra és 137 bankra, 2009-2014 júliusa közötti időszakra kiterjedő vizsgálatuk szerint a nemzetközi befektetők nem érzékelik a várható veszteségek szerinti értékvesztésképzés jelentőségét.

Covas és Nelson (2018) tanulmányukban azt kívánták vizsgálni, hogy ha a válság időszakában a várható értékvesztés modelljét alkalmazták volna, az milyen banki döntéseket eredményezett volna. A modellezés során a 2005-2013 közötti időszakot vizsgálva, arra következtetésre jutottak, hogy a várható veszteségen alapuló módszer használata ciklikusabb becslét ad a felmerült veszteségen alapuló modellnél. Eredményeik alapján mélyebb válságra számíthattunk volna, mert a bankok hitelezési tevékenysége további 9\%-kal esett volna vissza. Az új szabályok szerint minden hitel esetében várható veszteséget kellett volna meghatározni az eredeti hitelösszegre, emiatt a bankok abban lettek volna érdekeltek, hogy a kockázatos ügyfelek számára ne folyósítsanak hitelt, mivel azonnali veszteséget kellett volna elkönyvelniük.

Lu és Nikolaev (2019) kutatásai az új standard bevezetése során meghatározott értékvesztési tartalék gazdasági hatásaira irányultak. Véleményük szerint a felmerült veszteség alapján képzett értékvesztéssel szemben a várható értékvesztés jóval informatívabb, és anticiklikus módon viselkedik. A vizsgálat eredménye szerint a várható értékvesztésen alapuló modell alkalmazása a következő években magasabb tőkeköltséget eredményezhet, míg a túl alacsonyan meghatározott várható értékvesztés torzíthatja az adott bank hitelezési, finanszírozási és osztalékdöntéseit.

Wheeler (2019) szerint a nagy bankoknál erősebb a kapcsolat a meg nem képzett várható veszteségek mértéke és a tőzsdei ár alakulása között. A nagy bankok nagyobb információs bázisa miatt a befektetők képesek jobban megérteni az élettartam végéig számszerüsített várható veszteség mértékét. Wheeler szerint a befektetők beépítik a várható veszteségekre vonatkozó információkat a részvények árába, de ennek mértékére a szerző sem tudott pontos becslést adni. Az adott bank átláthatósága tovább növekedhet, ha a döntéshozók saját privát információikat - amelyeket a befektetők más forrásból nem tudnak beszerezni - beépítik a várható veszteségre vonatkozó becsléseikbe. 
Cantrell-McInnis-Yust (2014) tanulmányukban azt vizsgálták, hogy a hitelek valós értéke vagy azok bekerülési értéke ad-e hasznosabb információt a hitelek értékvesztése tekintetében. Elemzésükben kiemelik, hogy a bankszektor által elszámolt hitelezési veszteségeknek súlyos és széleskörü gazdasági következményei lehetnek. Megállapították, hogy a hitelek nettó bekerülési értéke jobban használható a jövőbeli értékvesztések becslésére, mint azok valós értéke.

Kund és Rugilo (2019) cikkükben az IFRS 9 szerinti várható értékvesztési modellnek a pénzügyi stabilitásra vonatkozó hatását vizsgálták. A szabályozás a felmerült veszteségmodellről (IAS 39) való áttéréssel két ellentétesen ható erőt szabadított fel, amelyek nettó hatása továbbra is kétértelmű a szerzők szerint. Miközben a veszteségek időben történő elszámolása a prociklikus hatások enyhítésével elősegíti a pénzügyi stabilitást, ugyanakkor gyengíti a tőkemegfelelést, potenciálisan ellentételezve az előbbiekben megfogalmazott előnyt. A szerzők kiemelik a „sziklahatás” fontosságát. Ahogy az a 2. ábrán látható: az IAS 39 csak az élettartam végén, a 3. kategóriába kerüléskor, hirtelen engedte a nagyarányú veszteségek leírását. Ezzel szemben az IFRS 9 ezt fokozatosabban engedi elszámolni.

2. ábra

„Sziklahatás”

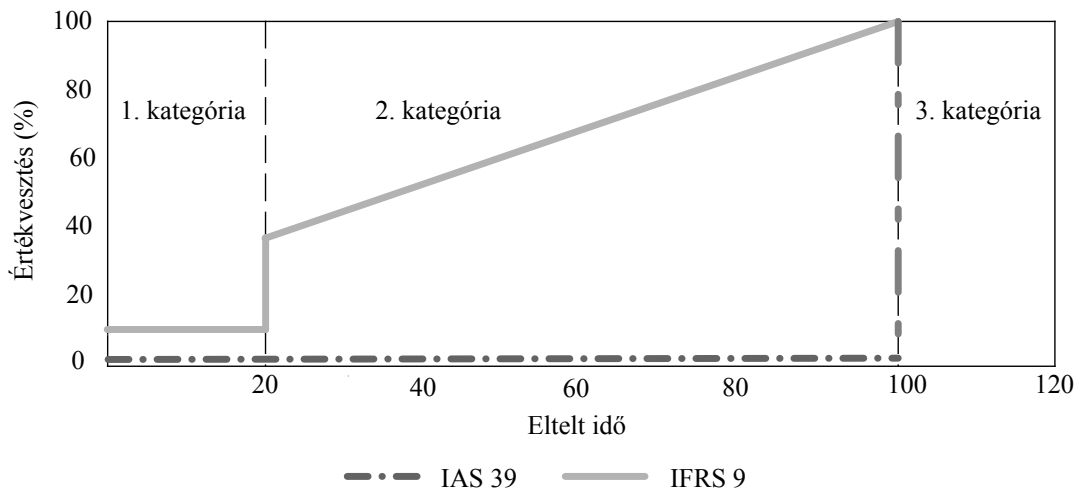

Forrás: Kund-Rugilo (2019)

Kund és Rugilo szerint az IFRS 9 bevezetése sikeresen csökkentette a „sziklahatás" súlyosságát; ezt a célt a várható hitelveszteségek előzetes megképzése révén sikerült elérni. Ennek eredményeként a kevésbé biztonságos hitelek magasabb költségekkel járnak a kezdeti megjelenítéskor, ami a bankok hitelkínálatának sokkjához vezethet, és megakadályozhatja a bankvezetőket abban, hogy ilyen kölcsönöknek másodlagos piacot szerezzenek, tehát az eszköz minősége az új számviteli standard szerint fontosabbá válik. 


\section{HIPOTÉZISEK}

Az IAS 39-ről az IFRS 9-re történő áttérés során a szabályváltozások három irányba hatottak, így hipotéziseink is erre fókuszálnak. Az első hatásmechanizmus a pénzügyi instrumentumok besorolásának megváltozását célozta. Ennek egyik fö célcsoportja a korábban „értékesíthető pénzügyi instrumentumként” besorolt, az IAS 39 szerint az OCI-val szemben értékelt kategória volt. Míg korábban ez a kategória az „egyéb” funkcióját töltötte be, tehát jobbára azok az instrumentumok kerültek ide, amelyek máshová nem voltak besorolhatók, a szabályváltoztatás után a pénzintézeteknek alaposabban meg kellett vizsgálniuk ezeket a vagyonelemeket. Vizsgálatuk eredményeképpen a tartási célnak legjobban megfelelő csoportba kellett őket átsorolniuk. Más, kisebb jelentőségű szabályváltozások - amelyeknek a részletes ismertetésére itt most nem térünk ki - szintén azt eredményezték, hogy a pénzintézeteknek instrumentumaik besorolását érdemben meg kellett változtatniuk. Ehhez a tényhez igazodik első hipotézisünk:

H1: A pénzügyi instrumentumok szerkezetének mérlegen belüli megváltozása érdemben hatott az adott pénzintézet piaci árfolyamának alakulására.

A szabálymódosítás másik fő iránya az értékvesztés elszámolási logikájának alapvető megváltozása. Azzal, hogy a szabályozás a múltra alapozott értékvesztés helyett a jövőbeni eseményekből vezeti le az értékvesztést, új, a számvitelben szokatlan szemlélet jelent meg. Minden előzetes szakmai várakozás abba az irányba mutatott, hogy a realizált hitelezési veszteségről (impairment) várható hitelezési veszteségre (ECL) történő áttérés az értékvesztés volumenének növekedését eredményezi. Ehhez igazodik második hipotézisünk:

H2: Az értékvesztés elszámolásának változása érdemben hatott az adott pénzintézet piaci árfolyamának alakulására.

Az értékvesztés elszámolásának előbb tárgyalt változása áttételesen hatással van a pénzintézet mérlegföösszegére - az előzetes szakmai várakozások alapján tendenciájában csökken. Vélhetően ez a változás a pénzintézetek méretéhez képest nagyon kis mértékủ. Kontrollváltozóként amúgy is szokás a vizsgált vállalkozás méretével kapcsolatos változót a modellbe építeni, és mi most ezt összekötjük azzal a ténnyel, hogy a szabályváltozás áttételesen a mérlegföösszeg változását vonja maga után.

H3: A mérlegföösszeg változása érdemben hatott az adott pénzintézet piaci árfolyamának alakulására. 
Az utolsó hipotézisünk az információk rendelkezésre állására fókuszál. A standard nem tartalmaz olyan szabályt, amely egy konkrét időponthoz kötné az IFRS 9-re való áttéréssel kapcsolatos adatok közzétételét. A pénzintézetek - saját döntésük alapján - három lehetőség közül választhattak:

1) A 2017-es évről készült beszámolóban, annak részeként tehették közzé először az IFRS 9 szerinti új adataikat; vagy

2) a 2018 első negyedévéről készült köztes beszámoló részeként is közzétehették az IFRS 9 szerinti új adataikat; vagy

3) a készülő beszámolóktól függetlenül, külön tájékoztató anyagot szentelhettek az IFRS 9 változásának.

A harmadik - tehát a külön kiadvány - esetében ennek mindig az év végi és a negyedéves beszámoló közé kellett esnie. Ehhez kapcsolódik negyedik hipotézisünk:

H4: Az a körülmény, hogy az IFRS 9-es információkat milyen formában hozta nyilvánosságra a pénzintézet, érdemben hatott az adott pénzintézet piaci árfolyamának alakulására.

Ezen négy hipotézis mentén vizsgáljuk, hogy milyen hatása volt az IFRS 9 bevezetésének a pénzintézetek piaci árfolyamának alakulására. Itt is - és később, a módszertani részben is - hangsúlyozni kívánjuk: célunk azon számviteli adatoknak, illetve adatköröknek az azonosítása, amelyek a piaci árfolyamra szignifikáns hatást gyakoroltak. Nem cél, hogy konkrét regressziós paraméterek segítségével magyarázzuk az árfolyamok alakulását.

\subsection{Adatbázis}

Vizsgálatunkat 91 európai tőzsdéin jegyzett pénzintézet IFRS szerint készített beszámolóira, illetve ezen pénzintézetek napi tőzsdei záró árfolyamaira alapoztuk. A tőzsdei árfolyamadatokat a Yahoo Finance felületéről gyüjtöttük. 


\section{3. táblázat}

A mintában szereplö bankok országonkénti megoszlása

\begin{tabular}{lc}
\hline Ország & Bankok száma, db \\
\hline Ausztria & 5 \\
Belgium & 3 \\
Dánia & 3 \\
Finnország & 2 \\
Franciaország & 4 \\
Görögország & 5 \\
Hollandia & 5 \\
Írország & 4 \\
Lengyelország & 5 \\
Lettország & 1 \\
Nagy-Britannia & 6 \\
Németország & 3 \\
Norvégia & 2 \\
Olaszország & 12 \\
Oroszország & 5 \\
Románia & 1 \\
Spanyolország & 5 \\
Svájc & 6 \\
Svédország & 7 \\
Törökország & 7 \\
Összesen & $\mathbf{9 1}$ \\
\hline
\end{tabular}

Forrás: saját szerkesztés

Az IFRS szerint készített beszámolók két típusát használtuk. Az egyik a 2017. december 31-ei fordulónappal készített beszámolók, a másik a pénzintézetek negyedéves időszaki pénzügyi jelentései. A beszámolók minden esetben az éppen hatályos jogszabályi állapotnak megfelelő szabályrendszer alapján készültek, tehát a 2017-es évet lezáró beszámolók még a régi IAS 39 szerinti elszámolásokat tartalmazzák, a 2018-ban közzétett időszaki beszámolók pedig már az új IFRS 9 szerint készültek.

Mivel a szabályok lehetőséget adtak rá, így a pénzintézetek választhattak, hogy milyen formában teszik közzé az IFRS 9-re való áttérés adatait. Lehetőségük volt a 2017-es évet lezáró beszámoló részeként vagy különálló tájékoztató kiadványban nyilvánosságra hozni. ${ }^{2}$

2 Megjegyzendő: a standard lehetőséget adott arra, hogy a pénzintézet mellőzze a részletező adatok közzétételét. Ezzel a lehetőséggel szerencsére nagyon kevesen éltek, azonban ezen pénzintézeteket ki kellett hagynunk a vizsgálódásunkból, így alakult ki a 91 vállalkozást tartalmazó minta. 
A beszámolók alapján az alábbi adatokat gyüjtöttük minden pénzintézettel kapcsolatban (a Mellékletben részletes szószedet található):

4. táblázat

Pénzügyi adatok

\begin{tabular}{ll}
\hline Név & \multicolumn{1}{c}{ Megjegyzés } \\
\hline Mérlegföösszeg & $\begin{array}{l}\text { Eredménnyel szemben értékelt pénzügyi eszköz } \\
\text { FVTPL }\end{array}$ \\
EVOCI szabályozás szerint kereskedési célú pénzügyi eszköz) \\
Egyéb átfogó eredménnyel (OCI) szemben értékelt pénzügyi \\
eszköz (régi szabályozás szerint értékesíthető pénzügyi eszköz) \\
AC & $\begin{array}{l}\text { Amortizált bekerülési értéken nyilvántartott } \\
\text { pénzügyi eszköz } \\
\text { Értékvesztés }\end{array}$ \\
Régi szabály (IAS 39) szerint számított értékvesztés \\
ECL & $\begin{array}{l}\text { Várható hitelezési veszteség; } \\
\text { új szabály (IFRS 9) szerint számított értékvesztés }\end{array}$ \\
\hline
\end{tabular}

Forrás: saját szerkesztés

A vizsgált változók leíró statisztikái a Mellékletben találhatók. A pénzügyi adatokat három időpontra gyüjtöttük:

1) 2017. december 31-i fordulónapra, ezeket a régi (IAS 39) szerinti szabályok alapján határozták meg;

2) 2018. január 1-i „fordulónapra”, itt a december 31-i adatokat az új, IFRS 9 szerinti szabályok alapján számították újra (ez lehetett a beszámoló része vagy külön kiadvány); valamint

3) 2018. március 31-ére vonatkozóan a 2018 első negyedév vége után közzétett időszaki adatokat tekintettük.

A vizsgált árfolyamadatokat a beszámolók nyilvánosságra hozatalához igazítottuk. Eszerint a 2017-es beszámolót 2018. február-március folyamán tették közzé, ez az adat minden pénzintézet esetében nyilvános és visszakereshető. A 2018 első negyedévéről készült időszaki jelentéseket 2018. április-május folyamán tették közzé - az adatok az előzőek mintájára szintén rendelkezésre állnak. Az árfolyamadatokat a közzétételek időpontjához kapcsolódóan gyüjtöttük úgy, hogy a közzététel előtti és utáni 5-5 nap napi záró árfolyamának átlagát számoltuk. 


\subsection{A modell}

A modellépítés folyamatát a 3. ábra mutatja be $3+1$ lépésben. Az ábra az első három lépést mutatja be, a negyedik lépés - az időváltozó bevezetése - már áttekinthetetlenné tenné az ábrát, így azt csak a föszövegben fejtjük ki. A könnyebb érthetőség érdekében a Mellékletben szószedetet is közreadunk az összes kódolással. Vizsgálatunk során a pénzintézetek árfolyamváltozását vizsgáljuk 3 időpontban:

1) a 2017-es beszámoló közzétételekor;

2) a 2018 első negyedévi beszámoló közzétételekor;

3) a 2017-es és a 2018 első negyedévi beszámoló közzététele között eltelt teljes időszakban.

Minden egyes esetben ismert a közzététel pontos dátuma, és minden esetben ezt a dátumot megelőző és követő 5-5 kereskedési nap záró árfolyamainak átlagát vettük alapul. Bár az 5-5 nap hosszúságú periódus választása önkényes, két dolgot azonban meg kell jegyeznünk. Vizsgálatunkba az azonnal kiváltott hatást $(+/-5$ nap) és az év végi és a negyedéves beszámoló között eltelt (90+ nap) negyedév során kiváltott hatást is be tudjuk építeni. Más szerzők által használt hosszabb (tipikusan 30-180 nap közötti) periódusok olyan vizsgálatokban fordulnak elö, amikor egy hatás időbeli lefutását kívánják elemezni.

\section{3. ábra}

\section{A modellépítés folyamata}

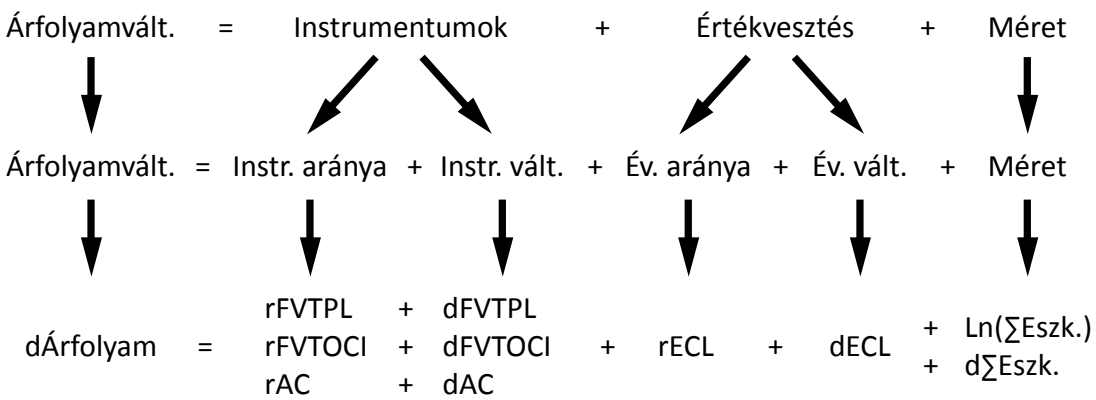

Forrás: saját szerkesztés

Az árfolyamváltozást 3 hatással kívánjuk magyarázni:

1) a pénzügyi instrumentumok belső szerkezetével,

2) az instrumentumokra elszámolt értékvesztéssel,

3) a pénzintézet méretével. 
Vizsgálatainkat egy külön lépésben kiegészítjük az IFRS 9-es új szabályok alkalmazásának közzétételi időpontjával is.

A modellt a következő lépésekben bontjuk változókra (minderről részletes leírást közlünk a Mellékletben):

1. Elöször az instrumentumokat és az értékvesztést kell megbontani azok mérlegföösszeghez viszonyított arányára („r” előtag jelöli), illetve a saját, előző időszaki összegéhez viszonyított százalékos változásra („d” előtag jelöli).

2. A méret esetében a 2017. 12. 31-i mérlegföösszeg természetes alapú logaritmusát és a következő időszakban a mérlegfőösszeg saját, előző időszaki összegéhez viszonyított százalékos változását számoljuk.

3. Következö lépésben - a szabályozásnak megfelelően - az instrumentumok tovább bomlanak 3 fajtára (FVTPL, FVTOCI és AC).

4. Majd utolsó lépésben mindegyik változót dátum szerint is bontjuk aszerint, hogy a 2017. 12. 31-i (régi szabály szerinti), 2018. 01. o1-i (új szabály szerinti) vagy 2018. 03. 31-i állapot szerint keletkezett.

Az adatokat SPSS segítségével, OLS-regresszióval vizsgáltuk. A regresszió összeállításánál „enter” és „backward” módszerrel vettük figyelembe a magyarázó változókat. Az „enter” módszert akkor alkalmaztuk, amikor a magyarázó változókat teljes körüen figyelembe vettük. A „backward” módszer alkalmazására azért került sor, mert gyors és hatékony módszernek bizonyult, amikor azt vizsgáltuk, hogy mely magyarázó változókat lehetne elhagyni a modellből úgy, hogy annak magyarázó ereje javuljon.

A „backward” módszernek köszönhetően az SPSS nagy mennyiségű modellt vizsgál minden esetben, ezek közül azokat választjuk, amelyek

- a varianciaanalízis (ANOVA) alapján 10\%-os szignifikanciaszinten szignifikánsak, és

- a korrigált $\mathrm{R}^{2}$ értékük a létrejövő modellek közül a legmagasabb.

Ennek a két választási szempontnak köszönhetően olyan modelleket is kiválasztottunk, amelyekben néhány változó 10\%-os szignifikanciaszinten nem gyakorol szignifikáns hatást. Ennél jóval szigorúbb statisztikai feltételeket is meg lehetne határozni, azonban abban az esetben a modellek magyarázó változói drasztikusan csökkennének. (A 10\% feletti szignifikanciaszintet minden esetben külön jelezzük.) 


\subsection{Hipotézisvizsgálat}

Vizsgálatunk során először három időpontban:

1) a 2017-es beszámoló közzétételekor,

2) a 2018 első negyedévi beszámoló közzétételekor,

3) a 2017-es és a 2018 első negyedévi beszámoló közzététele között eltelt teljes időszakban vizsgáltuk az árfolyamok alakulását magyarázó változókat.

Újra hangsúlyozzuk, hogy a modellezés során nem az egyes magyarázó változók paraméterbecslésére koncentráltunk. Célunk azon számviteli adatoknak, illetve adatköröknek a beazonosítása volt, amelyek a piaci árfolyamra szignifikáns hatást gyakoroltak. Nem volt cél, hogy konkrét regressziós paraméterek segítségével magyarázzuk az árfolyamok alakulását. Vizsgálatunk következő lépése, hogy megnéztük, a kiválasztott modellek mely változók körében mutattak szignifikáns kapcsolatot.

5. táblázat

Regressziós elemzés eredménye a pénzügyi intézmények teljes körére

\begin{tabular}{|c|c|c|c|c|}
\hline Modell & $\begin{array}{l}\text { Eredmény- } \\
\text { változó }\end{array}$ & $\begin{array}{l}\text { Modell szig. } \\
\text { (F-próba) }\end{array}$ & $\begin{array}{c}\text { Korrigált } \\
\qquad \mathbf{R}^{2}\end{array}$ & $\begin{array}{c}\text { Szignifikáns magyarázó } \\
\text { változók }\end{array}$ \\
\hline 1 & drPrice_18_17 & 0,104 & 0,043 & $\begin{array}{l}\text { rFVTPL_2017 } \\
\text { rFVTOCI_2017 } \\
\text { rAC_2017 } \\
\text { dAC_201801 }\end{array}$ \\
\hline 2 & drPrice_18q & 0,07 & 0,191 & $\begin{array}{l}\text { rFVTPL_201801 (szig. 0,159) } \\
\text { rFVTPL_2018q1 } \\
\text { dFVTPL_2018q1 } \\
\text { rFVTOCI_2017 } \\
\text { rFVTOCI_201801 } \\
\text { dFVTOCI_201801 (szig. 0,135) } \\
\text { dFVTOCI_2018q1 } \\
\text { rAC_2017 } \\
\text { rAC_201801 } \\
\text { dAC_201801 } \\
\text { rECL_201801 } \\
\text { rECL_2018q1 } \\
\text { dECL_2018q1 }\end{array}$ \\
\hline
\end{tabular}




\begin{tabular}{|c|c|c|c|c|}
\hline Modell & $\begin{array}{l}\text { Eredmény- } \\
\text { változó }\end{array}$ & $\begin{array}{l}\text { Modell szig. } \\
\text { (F-próba) }\end{array}$ & $\begin{array}{l}\text { Korrigált } \\
\mathbf{R}^{2}\end{array}$ & $\begin{array}{c}\text { Szignifikáns magyarázó } \\
\text { változók }\end{array}$ \\
\hline \multirow{4}{*}{3} & \multirow{4}{*}{ drPrice_18q_17 } & \multirow{4}{*}{0,01} & \multirow{4}{*}{0,261} & $\begin{array}{l}\text { lnTotalAssets_2017 (szig. 0,109) } \\
\text { dTotalAssets_201801 } \\
\text { dTotalAssets_2018q1 (szig 0,247) } \\
\text { rFVTPL_201801 (szig. 0,275) } \\
\text { dFVTPL_2018q1 }\end{array}$ \\
\hline & & & & rFVTOCI_2017 \\
\hline & & & & $\begin{array}{l}\text { rAC_2017 } \\
\text { rAC_201801 } \\
\text { rAC_2018q1 } \\
\text { dAC_201801 (szig. 0,108) } \\
\text { dAC_2018q1 }\end{array}$ \\
\hline & & & & $\begin{array}{l}\text { rECL_201801 } \\
\text { rECL_2018q1 } \\
\text { dECL_2018q1 }\end{array}$ \\
\hline
\end{tabular}

Forrás: saját szerkesztés

Ahogy az az 5. táblázatból látszik, az idő előrehaladtával a modellek leíró statisztikái gyors ütemben javulnak. A 2017-es év beszámolójának közzétételekor a pénzügyi adatok és az árfolyamváltozás között nem is találunk 10\%-on szignifikáns modellt; igaz, alig rosszabb a próba értéke 10\%-nál. Viszont az 1. modell magyarázó ereje is messze a legalacsonyabb, és csak 4 változó bizonyult szignifikánsnak.

Ahogy áttérünk a 2018. első negyedévi beszámoló hatásának vizsgálatára, a modell tulajdonságai drasztikusan javulnak. A 2. modell 10\%-os szignifikanciaszinten szignifikáns, magyarázóereje közel 20\%. A szignifikáns magyarázó változók száma is többszörösére nő: 4-ről 11-re, és két olyan változó is van, amely valamivel a 10\%-os szignifikanciaszint felett mutat kapcsolatot.

A teljes negyedévet átfogó 3. modell 1\%-os szignifikanciaszinten szignifikáns, magyarázóereje több, mint $25 \%$, és 10 szignifikáns, valamint 4 nem szignifikáns magyarázó változót tartalmaz. Megjegyzendő, hogy ez az első alkalom, ahol a pénzintézet méretével kapcsolatos változó bekerült a szignifikáns elemek közé.

Ezek alapján tehát - későbbi vagy hosszabb időszakot vizsgálva - az IFRS 9 szabályváltozásai egyre szélesebb körben és egyre nagyobb mértékben kezdenek el hatni az árfolyamok változására. Azt gondoljuk: az eredmények azt mutatják, a piac szereplőinek időre volt szükségük, hogy „megszokják” és elkezdjék alkalmazni az új információkat a döntéseik során. 
Van azonban még egy körülmény, amelyet eddig nem vettük figyelembe. Az IFRS szabályozása választási lehetőséget biztosított a pénzintézeteknek, hogy mikor tesznek közzé az új szabályok szerint megállapított adatokat. Ez történhetett a 2017-es beszámoló részeként, vagy az IFRS 9 első alkalmazását bemutató, külön tájékoztatóban, vagy a 2018-as első negyedévi beszámoló részeként. Következő lépésben azt vizsgáltuk meg, hogy a három lehetőség közül mely hitelintézet mikor tette közzé IFRS 9-es adatait. Az eredményeket a 6. táblázat foglalja össze.

\section{6. táblázat}

Regressziós elemzés eredménye azon pénzügyi intézményekre, amelyek IFRS 9-es adatot már közöltek

\begin{tabular}{|c|c|c|c|c|}
\hline Modell & $\begin{array}{l}\text { Eredmény- } \\
\text { változó }\end{array}$ & $\begin{array}{c}\text { Modell szig. } \\
\text { (F-próba) }\end{array}$ & Korrigált $\mathrm{R}^{2}$ & Magyarázó változók \\
\hline 4 & $\begin{array}{l}\text { drPrice_18_17 } \\
\text { Csak azon } \\
\text { pénzintézetek, } \\
\text { amelyek 2017-es } \\
\text { beszámolójukban } \\
\text { IFRS 9-re } \\
\text { vonatkozó adatokat } \\
\text { közöltek. }\end{array}$ & 0,038 & 0,232 & $\begin{array}{l}\text { dTotalAssets_201801 } \\
\text { rIAS39impaim } \\
\text { rECL_201801 } \\
\text { dECL_201801 }\end{array}$ \\
\hline 5 & $\begin{array}{l}\text { drPrice_18q } \\
\text { Csak azon } \\
\text { pénzintézetek, } \\
\text { amelyek 2017-es } \\
\text { beszámolójukban } \\
\text { vagy külön } \\
\text { beszámolóban } \\
\text { IFRS 9-re } \\
\text { vonatkozó } \\
\text { adatokat közöltek. }\end{array}$ & 0,07 & 0,484 & $\begin{array}{l}\text { rFVTPL_2017 } \\
\text { rFVTPL_2018q1 } \\
\text { dFVTPL_2018q1 } \\
\text { rFVTOCI_201801 } \\
\text { rFVTOCI_2018q1 } \\
\text { dFVTOCI_201801 } \\
\text { (szig. 0,153) } \\
\text { dFVTOCI_2018q1 } \\
\text { rAC_2017 } \\
\text { rAC_2018q1 } \\
\text { dAC_201801 } \\
\text { rIAS39impaim } \\
\text { rECL_2018q1 } \\
\text { dECL_2018q1 }\end{array}$ \\
\hline
\end{tabular}

Forrás: saját szerkesztés

A 4. modell az 1. modell módosításaként fogható fel: most csak azon pénzintézetek körére végeztük el az elemzést, amelyek már a 2017-es beszámolóikban közre- 
adták az IFRS 9-es szabályokkal számolt, friss adataikat. A változás - nem meglepő módon - szembetűnő. A modell 5\%-os szignifikanciaszinten szignifikáns, magyarázó ereje nagyobb, mint 20\%.

Az 5. modell a 2. modell módosításaként fogható fel: itt azon pénzintézetek körét vizsgáltuk, amelyek 2017-es beszámolójuk keretében, vagy külön tájékoztató anyagban már nyilvánosságra hozták IFRS 9-es adataikat. ${ }^{3}$ A modell 10\%-os szignifikanciaszinten szignifikáns, magyarázó ereje közel 50\%, 12 szignifikáns és 1 nem szignifikáns változót tartalmaz. Megjegyzendő azonban, hogy a magas magyarázó erő mögött vélhetően a pénzügyi adatokban természetes módon meglévő autokorreláció és multikollinearitás is szerepet játszik. Az eredményekről azt feltételezzük, hogy az eredmények mögött felfedezhetjük az első negyedév során felhalmozódott befektetői tudásnak az árakban tükröződő megjelenését.

Többször hangsúlyoztuk: vizsgálatunk célja az volt, hogy beazonosítsuk azokat az adatköröket, amelyek az IFRS 9 bevezetésével kapcsolatban az árfolyamokra hatást gyakoroltak. Ennek érdekében a 7. és 8. táblázatban a szignifikáns kapcsolatot mutató változókat foglaltuk össze.

A modellezés eredményét a 7 . táblázat foglalja össze. A táblázat oszlopaiban a modellek, a sorokban a változók teljes köre található. A jelölések a szignifikáns kapcsolatokat mutatják.

Regressziós elemzésünk eredményeit - a 3. ábrához igazodó szerkezetben - a 7 . táblázat foglalja össze. Ebből látható, hogy a 2017-es beszámoló közzétételéhez kapcsolódó vizsgálatunk esetében csak a 4. modell bizonyult értékelhetőnek. A 4. modell kimondottan az IFRS 9 által bevezetett új értékvesztés-számítást (ECL) és az ennek is betudható vagyonváltozást (dTotalAssets) mutatja meghatározónak. Vélhetően itt azt a hatást érhetjük tetten, hogy azon pénzintézetek, amelyek már ekkor részletes IFRS 9 adatokat nyújtottak, inkább a figyelem középpontjába kerültek, és a piacok elkezdték az új információkat is beépíteni az árakba, míg a pénzintézetek egészét ez még nem befolyásolta szignifikáns módon.

A többi modell (2., 3., 5. modell) sokkal homogénebb képet mutat mind magyarázóerőben, mind az érintett változók körében. Ebből azt a következtetést vonhatjuk le, hogy az új típusú információk fokozatosan, egyre jobban és egyre szélesebb körben épültek be a döntésekbe.

3 Megjegyzendő, hogy más kombinációkra is elvégeztük a vizsgálatokat, de azok nem vezettek eredményre. 


\section{7. táblázat}

A modellezés részletes eredményei

\begin{tabular}{|c|c|c|c|c|c|c|}
\hline & & 4 & 2 & 5 & 3 \\
\hline & & Eredményváltozó & drPrice_18_17 & \multicolumn{2}{|c|}{ drPrice_18q } & drPrice_18q_17 \\
\hline \multirow{15}{*}{ 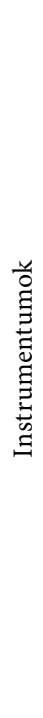 } & \multirow{15}{*}{ 胥 } & rFVTPL_2017 & & & $\mathrm{x}$ & \\
\hline & & rFVTPL_201801 & & szig. 0,159 & & szig. 0,275 \\
\hline & & rFVTPL_2018q1 & & $\mathrm{x}$ & $\mathrm{x}$ & $\mathrm{x}$ \\
\hline & & rFVTOCI_2017 & & $\mathrm{x}$ & & $\mathrm{x}$ \\
\hline & & rFVTOCI_201801 & & $\mathrm{x}$ & $\mathrm{x}$ & \\
\hline & & rFVTOCI_2018q1 & & & $\mathrm{x}$ & \\
\hline & & rAC_2017 & & $\mathrm{x}$ & $\mathrm{x}$ & $\mathrm{x}$ \\
\hline & & rAC_201801 & & $\mathrm{x}$ & & $\mathrm{x}$ \\
\hline & & rAC_2018q1 & & & $\mathrm{x}$ & $\mathrm{x}$ \\
\hline & & dFVTPL_201801 & & & & \\
\hline & & dFVTPL_2018q1 & & $\mathrm{x}$ & $\mathrm{x}$ & \\
\hline & & dFVTOCI_201801 & & szig. 0,135 & szig. 0,153 & \\
\hline & & dFVTOCI_2018q1 & & $\mathrm{x}$ & $\mathrm{x}$ & \\
\hline & & dAC_201801 & & $\mathrm{x}$ & & szig. 0,108 \\
\hline & & dAC_2018q1 & & & $\mathrm{x}$ & $\mathrm{x}$ \\
\hline \multirow{5}{*}{ 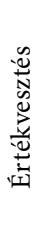 } & \multirow{5}{*}{ 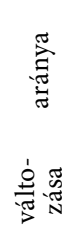 } & rIAS39impaim & $\mathrm{x}$ & & $\mathrm{x}$ & \\
\hline & & rECL_201801 & $\mathrm{x}$ & $\mathrm{x}$ & $\mathrm{x}$ & $\mathrm{x}$ \\
\hline & & rECL_2018q1 & & $\mathrm{x}$ & & $\mathrm{x}$ \\
\hline & & dECL_201801 & $\mathrm{x}$ & & & \\
\hline & & dECL_2018q1 & & $\mathrm{x}$ & $\mathrm{x}$ & $\mathrm{x}$ \\
\hline & \multirow{5}{*}{ 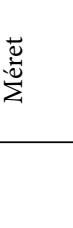 } & lnTotalAssets_2017 & & & & szig. 0,109 \\
\hline & & dTotalAssets_201801 & $\mathrm{x}$ & & & $\mathrm{x}$ \\
\hline & & dTotalAssets_2018q1 & & & & szig 0,247 \\
\hline & & Szig. & 0,038 & 0,07 & 0,07 & 0,01 \\
\hline & & Kor. R2 & 0,232 & 0,191 & 0,484 & 0,261 \\
\hline
\end{tabular}

Forrás: saját szerkesztés

Végezetül a 8. táblázat - a 3. ábrához igazodó szerkezetben - a modellezés eredményeit tömörítve tartalmazza. A tömörítés lényege, hogy azt számoljuk meg: az adott tényezőhöz kapcsolódó változók hány esetben mutatnak szignifikáns kapcsolatot? 
8. táblázat

A modellezés összevont eredményei

\begin{tabular}{|c|c|c|c|c|c|c|c|c|}
\hline \multicolumn{3}{|c|}{$\begin{array}{c}\text { Modell } \\
\text { Eredményváltozó }\end{array}$} & \multirow[t]{7}{*}{$\begin{array}{c}4 \\
\text { drPrice_18_17 }\end{array}$} & \multicolumn{2}{|c|}{$\begin{array}{cc}2 & 5 \\
\text { drPrice_18q }\end{array}$} & \multirow{2}{*}{$\begin{array}{c}\text { 3 } \\
\text { drPrice_18q_17 } \\
1\end{array}$} & \multirow{2}{*}{$\begin{array}{c}\begin{array}{c}\text { Össze- } \\
\text { sen }\end{array} \\
4\end{array}$} & \multirow[t]{2}{*}{$\begin{array}{c}\text { Mindösz- } \\
\text { szesen }\end{array}$} \\
\hline \multirow{6}{*}{ } & \multirow{3}{*}{ 恚 } & FVTPL & & 1 & 2 & & & \\
\hline & & FVTOCI & & 2 & 2 & 1 & 5 & \multirow[t]{2}{*}{16} \\
\hline & & $\mathrm{AC}$ & & 2 & 2 & 3 & 7 & \\
\hline & \multirow{3}{*}{ 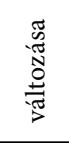 } & FVTPL & & 1 & 1 & & 2 & \\
\hline & & FVTOCI & & 1 & 1 & & 2 & 7 \\
\hline & & $\mathrm{AC}$ & & 1 & 1 & 1 & 3 & \\
\hline \multirow{2}{*}{ 座 } & 胥 & ECL & 2 & 2 & 2 & 2 & 8 & 8 \\
\hline & 递芯 & ECL & 1 & 1 & 1 & 1 & 4 & 4 \\
\hline \multirow{3}{*}{\multicolumn{2}{|c|}{ 离 }} & $\begin{array}{l}\text { Total- } \\
\text { Assets }\end{array}$ & 1 & & & 1 & 2 & 2 \\
\hline & & Szig. & 0,038 & 0,07 & 0,07 & 0,01 & - & - \\
\hline & & Kor. R2 & 0,232 & 0,191 & 0,484 & 0,261 & - & - \\
\hline
\end{tabular}

Forrás: saját szerkesztés

\section{KÖVETKEZTETÉSEK}

A 8. táblázat alapján hipotéziseink tesztelésére is lehetőségünk van. $H_{1}$-ben azt tételeztük fel, hogy a pénzügyi instrumentumok szerkezetének megváltozása érdemben befolyásolta az árfolyamok alakulását. Eredményeink alapján az instrumentumok szerkezetének megváltozása csak a 2018. első negyedévi jelentések megjelenésekor fejtett ki szignifikáns hatást. Szembetűnő azonban, hogy az instrumentumok mindenkori állománya jóval nagyobb hatást fejt ki, mint a változásuk. Ennek alapján H1-et elvetjük, mert a változást mérő változóink csak a 2018. első negyedévi, rövid távú árfolyammozgások esetében volt szignifikáns; sem a 2017. végi, sem a hosszabb távú árfolyamváltozásra nem volt hatással. Az eredmények illeszkednek az irodalomhoz, amelyek a pénzügyi instrumentumok csoportosításának jelentőségét vizsgálják. Az irodalom elsősorban a 2008-as pénzügyi válság megoldásaként megjelenő állományváltozásokra fókuszál, ezzel szemben mi kutatásunkban egy pénzügyileg stabil időszakban vizsgáltuk ezeket az összefüggéseket. 
A $H_{2}$ esetében az értékvesztés elszámolásának szignifikáns hatását tettük fel. A 8. táblázatból kitűnik, hogy az értékvesztés megváltozása mindegyik modell esetében szignifikáns hatást gyakorolt az árfolyamokra. Megjegyzendő azonban, hogy az értékvesztés aktuális értékének itt is sokkal több esetben volt szignifikáns hatása, mint az érték megváltozásának. Ezek alapján $\mathrm{H}_{2}$-t elfogadjuk. Az új értékvesztési logika megerősíti a korábbi irodalom (Beaver et al., 1989) megállapításait, amely szerint a megképzett értékvesztés nagysága „biztonságérzetet” adhat a befektetők számára.

A $H_{3}$ esetében a mérlegföösszeg megváltozásának szignifikáns hatását tettük fel. A 8. táblázatból kitűnik, hogy messze ennek volt a legkisebb hatása az árfolyamok alakulására. Ennek alapján a $H_{3}$-at elvetjük.

A H4 esetében az IFRS 9-es információk nyilvánosságra hozatalának szignifikáns hatását tettük fel. Amennyiben a 4. és 5. modellt egymáshoz, illetve az első három modellhez viszonyítjuk, akkor egyértelmű, hogy azoknál a pénzintézeteknél, amelyek nem a beszámolójuk részeként, hanem külön kiadványban mutatták be IFRS 9-cel kapcsolatos adataikat, azoknál az új szabályokkal összefüggő változók széles köre gyakorolt szignifikáns hatást úgy, hogy modellünk magyarázóereje messze a legmagasabb. Ennek alapján a $\mathrm{H}_{4}$-et elfogadjuk.

A kutatásunk eredménye alapján megállapítható, hogy az új standard által elöírt változásokat a befektetők pozitívan értelmezték, hiszen a pénzügyi instrumentumok új csoportosítása a beszámoló átláthatóságát szolgálja, emellett az értékeléseket egyszerüsíti, és a megfelelően, előre megképzett értékvesztés a bankok részéről a prevenciót jelenti.

\section{FÜGGELÉK}

\section{A Covid-19-pandémia hatása az értékvesztés elszámolására}

A Covid-19-járvány világméretü kiterjedésével járó egészségügyi, társadalmi és gazdasági következmények hatással vannak a bankok kockázatkezelő tevékenységére, illetve az ezzel járó, az IFRS 9 standardban megfogalmazott értékvesztésképzési feladataira. Az Európai Központi Bank (EBC), az Európai Értékpapír-piaci Hatóság (ESMA), az Európai Bankfelügyeleti Hatóság (EBA), karöltve a Nemzetközi Számviteli Standard Testülettel (IASB), értelmezéseket fogalmaz meg iránymutatásként a speciális helyzet egységes kezelése érdekében az IFRS 9 standardban rögzített szabályokra vonatkozóan. Az egységes vélemény az, hogy a bankok az IFRS 9 szerinti értékvesztés elszámolásakor azt a standardból eredő, megfelelő rugalmassággal alkalmazzák a megfelelő mérlegelési gyakorlat mellett. 
Az első fontos kérdés, hogy a járvány során kialakult pénzügyi-gazdasági helyzet érinti-e a pénzügyi eszközöknek az IFRS 9 által meghatározott ECL-kosarakba való besorolását. A munkahelyek megszűnése számos háztartást sodort nehéz pénzügyi helyzetbe, továbbá a gazdasági entitások az elvesztett megrendelések miatt komoly veszteségeket kénytelenek elszenvedni, elszámolni. Mindezek alapján számos ország - köztük Magyarország is - olyan intézkedéseket foganatosított, amelyek révén a korábbiakban ütemezett adóságszolgálatok halasztást kaptak. A bevezetett törlesztési, kamatfizetési moratóriumok miatt szükséges-e a nyilvántartásba vételkor az 1. kosárba sorolt követelést a nemfizetés miatta 2. kosárba sorolni? Az EBC, ESMA, EBA ajánlásaiban kiemeli, hogy nem lehet a standardban megfogalmazottakat mechanikusan alkalmazni, így az - akár magánkezdeményezésü, akár jogszabályi - moratóriumok miatt kialakuló nemfizetések nem eredményezhetnek automatikusan átsorolást. Az ajánlások felhívják a figyelmet arra, hogy a hitelkockázat növekedésének vizsgálata jelenleg komplexebb elemzést kíván meg. Az Európai Bizottság közleményében kiemeli, hogy „a rövid távú likviditási szükségletek áthidalását célzó, teherkönnyítő intézkedések alkalmazása nem vezethet automatikusan szigorúbb számviteli vagy prudenciális kezeléshez, ha a pénzügyi helyzet egyébként nem romlik". A EBA szerint a moratórium új viszonyítási időpontot határoz meg a hitelfelvevők késedelmes napjainak számításakor, mindez hatással van a 30 napot meghaladó késedelem miatti hitelezési kockázat növekedésének vélelmezésére, továbbá a 90 napot meghaladó késedelem miatti nemteljesítés megállapítására is.

Az ajánlások kiemelik a hitelgaranciák szerepét a járványhelyzet okozta problémák kezelésénél. A különböző szervezetek által publikált ajánlásokban megfogalmazták, hogy ha egy kormány vagy más szervezet egy adott bankhitelhez garanciát nyújt a hitelfelvevőnek, akkor az adott hitelintézetnek ezt figyelembe kell vennie a várható hitelezési veszteség összegének számszerüsítésekor. A garancia a jövőben felmerülő veszteségeket kompenzálhatja, így csökkenti a bank által megképzendő értékvesztés összegét.

A különböző ajánlást nyújtó hatóságok felhívják a bankok figyelmét a tájékoztatás fontosságára. Megfelelő információkat kell közzétenni a várható veszteségek meghatározására vonatkozóan, megvizsgálva az optimista és pesszimista forgatókönyveket is. A beszámoló kiegészítő mellékletében be kell mutatni a Covid-19-válság hatására elfogadott, egyedi számviteli értékelési elveket, becslési metódusokat, döntéseket. Mindez lehetővé teszi a piaci szereplők számára az adott hitelintézet megítélését a hitelkockázati kitettség megállapítása érdekében. A transzparencia jelen helyzetben kiemelkedően fontos.

A ECB arra ösztönzi a bankokat, hogy a Covid-19 okozta hatások miatt éljenek az IFRS 9 standardra vonatkozó átmeneti intézkedésekkel, ami lehetővé teszi a várható veszteségek miatt képzett értékvesztések nagyságának csökkentését, és ez 
a bankok szavatolótőkéjére kedvezőbb hatást gyakorol. Az IFRS 9 bevezetésekor lehetett kérni 5 éves átmeneti időszakot az illetékes hatóságtól. Most az ECB a Bázeli Bankfelügyeleti Bizottsággal karöltve javasolja az 5 éves átmeneti időszak ismételt meghatározását.

\section{Néhány fontos ajánlás}

- Az Európai Központi Bank véleménye „az uniós prudenciális keretnek a Covid-19-világjárvánnyal összefüggésben történő módosításáról” (CON/2020/16), 2020. május 20.

- A Bizottság közleménye az Európai Parlamentnek és a Tanácsnak: „Bizottsági értelmező közlemény a számviteli és prudenciális kereteknek az uniós banki hitelezés megkönnyítése érdekében történő alkalmazásáról”. A vállalkozások és háztartások támogatása a Covid-19-járvány közepette, Brüsszel, 2020.4.28. $\operatorname{COM}(2020) 169$ final.

- Az Európai Parlament és a Tanács rendelete az 575/2013/EU rendeletnek és az (EU) 2019/876 rendeletnek a Covid-19-világjárvánnyal összefüggő kiigazítások tekintetében történő módosításáról, Brüsszel, 2020.4.28. COM(2020) 310 final.

- ESMA: „A Covid-19-járványnak a várható hitelezési veszteségek IFRS 9-nek megfelelő kiszámítására gyakorolt számviteli vonzatai” (Accounting implications of the COVID-19 outbreak on the calculation of expected credit losses in accordance with IFRS 9) címü, 2020. március 25-i nyilatkozata.

- A CEAOB 2020. március 25-i nyilatkozata azon területekröl, amelyek nagy jelentőséggel bírnak a Covid-19-járvány által a pénzügyi kimutatások ellenőrzésére gyakorolt hatás szempontjából (CEAOB emphasises the following areas that are of high importance in view of Covid-19 impact on audits of financial statements).

- Az IASB „IFRS 9 és a Covid-19 - A várható hitelezési veszteségek elszámolása az IFRS 9 Pénzügyi instrumentumok standard alkalmazásával a Covid-19világjárványból eredő jelenlegi bizonytalanságra való tekintettel” (IFRS 9 and Covid-19 - Accounting for expected credit losses applying IFRS 9 Financial Instruments in the light of current uncertainty resulting from the Covid-19 pandemic) címü, 2020. március 27-i nyilatkozata.

- $\mathrm{Az} \mathrm{EBH}$ „A prudenciális keretnek a nemteljesítés, az átstrukturálás és az IFRS 9 tekintetében történő alkalmazásáról a Covid-19-járvánnyal kapcsolatos intézkedések fényében" (Statement on the application of the prudential framework regarding Default, Forbearance and IFRS9 in light of COVID-19 measures) címü, 2020. március 25-i nyilatkozata. 


\section{MELLÉKLETEK}

\section{1. melléklet}

\section{A modell változói}

\begin{tabular}{|c|c|c|c|c|c|c|}
\hline $\begin{array}{l}\text { Megne- } \\
\text { vezés }\end{array}$ & Változó & Leírás & Változó & Leírás & Változó & Leírás \\
\hline \multirow{3}{*}{ 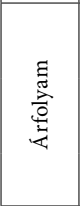 } & \multirow{3}{*}{ Price } & \multirow{3}{*}{$\begin{array}{l}\text { Adott pénzin- } \\
\text { tézet tőzzsdei } \\
\text { árfolyama }\end{array}$} & \multirow{3}{*}{ drPrice } & \multirow{3}{*}{$\begin{array}{l}\text { Price \%-os változása } \\
\text { a beszámoló közzé- } \\
\text { tételét megelőző és } \\
\text { követő 5-5 kereske- } \\
\text { dési napon }\end{array}$} & drPrice_18_17 & $\begin{array}{l}\text { drPrice a 2017-es } \\
\text { beszámolóhoz } \\
\text { kapcsolódóan }\end{array}$ \\
\hline & & & & & drPrice_18q & $\begin{array}{l}\text { drPrice a } 2018 \text { első } \\
\text { negyedévi beszámoló } \\
\text { hoz kapcsolódóan }\end{array}$ \\
\hline & & & & & drPrice_18q_17 & $\begin{array}{l}\text { drPrice a teljes vizs- } \\
\text { gált időszak alatt }\end{array}$ \\
\hline \multirow{15}{*}{ 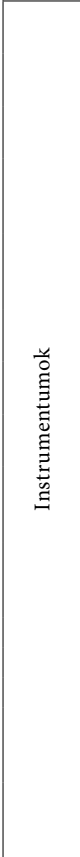 } & \multirow{5}{*}{ FVTPL } & \multirow{5}{*}{$\begin{array}{l}\text { Eredménnyel } \\
\text { szemben valós } \\
\text { értéken értékelt } \\
\text { intrumentum }\end{array}$} & \multirow{3}{*}{ rFVTPL } & \multirow{3}{*}{$\begin{array}{l}\text { FVTPL \%-os aránya } \\
\text { a mérlegföösszegen } \\
\text { belül }\end{array}$} & rFVTPL_2017 & $\begin{array}{l}\text { rFVTPL } \\
\text { 2017.12.31-én }\end{array}$ \\
\hline & & & & & rFVTPL_201801 & $\begin{array}{l}\text { rFVTPL } \\
\text { 2018.001.01-én }\end{array}$ \\
\hline & & & & & rFVTPL_2018q1 & $\begin{array}{l}\text { rFVTPL } \\
\text { 2018.03.31-én }\end{array}$ \\
\hline & & & \multirow{2}{*}{ dFVTPL } & \multirow{2}{*}{$\begin{array}{l}\text { FVTPL \%-os válto- } \\
\text { zása az előző idő- } \\
\text { szakhoz képest }\end{array}$} & dFVTPL_201801 & $\begin{array}{l}\text { FVTPL változá- } \\
\text { sa 2017.12.31-ről } \\
\text { 2018.01.01-re }\end{array}$ \\
\hline & & & & & dFVTPL_2018q1 & $\begin{array}{l}\text { FVTPL változása } \\
\text { 2018.01.01-röl } \\
\text { 2018.03.31-re }\end{array}$ \\
\hline & \multirow{5}{*}{ FVTOCI } & \multirow{5}{*}{$\begin{array}{l}\text { OCI-val } \\
\text { szemben valós } \\
\text { értéken értékelt } \\
\text { instrumentum }\end{array}$} & \multirow{3}{*}{ rFVTOCI } & \multirow{3}{*}{$\begin{array}{l}\text { FVTOCI \%-os } \\
\text { aránya a mérlegfö- } \\
\text { összegen belül }\end{array}$} & rFVTOCI_2017 & $\begin{array}{l}\text { rFVTOCI } \\
\text { 2017.12.31-én }\end{array}$ \\
\hline & & & & & rFVTOCI_201801 & $\begin{array}{l}\text { rFVTOCI } \\
2018.001 .01 \text {-én }\end{array}$ \\
\hline & & & & & rFVTOCI_2018q1 & $\begin{array}{l}\text { rFVTOCI } \\
\text { 2018.03.31-én }\end{array}$ \\
\hline & & & \multirow{2}{*}{ dFVTOCI } & \multirow{2}{*}{$\begin{array}{l}\text { FVTOCI \%-os } \\
\text { változása az előző } \\
\text { időszakhoz képest }\end{array}$} & dFVTOCI_201801 & $\begin{array}{l}\text { FVTOCI változása } \\
\text { 2017.12.31-ről } \\
\text { 2018.01.01-re }\end{array}$ \\
\hline & & & & & dFVTOCI_2018q1 & $\begin{array}{l}\text { FVTOCI változá- } \\
\text { sa 2018.01.01-röl } \\
\text { 2018.03.31-re }\end{array}$ \\
\hline & \multirow{5}{*}{$\mathrm{AC}$} & \multirow{5}{*}{$\begin{array}{l}\text { Amortizált be- } \\
\text { kerülési értéken } \\
\text { értékelt instru- } \\
\text { mentumok }\end{array}$} & \multirow{3}{*}{$\mathrm{rAC}$} & \multirow{3}{*}{$\begin{array}{l}\text { AC \%-os aránya a } \\
\text { mérlegföösszegen } \\
\text { belül }\end{array}$} & rAC_2017 & rAC 2017.12.31-én \\
\hline & & & & & rAC_201801 & rAC 2018.001.01-én \\
\hline & & & & & rAC_2018q1 & rAC 2018.03.31-én \\
\hline & & & \multirow{2}{*}{$\mathrm{dAC}$} & \multirow{2}{*}{$\begin{array}{l}\text { AC \%-os változása } \\
\text { az előző időszakhoz } \\
\text { képest }\end{array}$} & dAC_201801 & $\begin{array}{l}\text { AC változása } \\
\text { 2017.12.31-röl } \\
\text { 2018.01.01-re }\end{array}$ \\
\hline & & & & & dAC_2018q1 & $\begin{array}{l}\text { AC változása } \\
\text { 2018.01.01-röl } \\
\text { 2018.03.31-re } \\
\end{array}$ \\
\hline \multirow{5}{*}{ 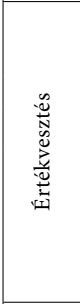 } & IAS39imp & $\begin{array}{l}\text { Értékvesztés } \\
\text { IAS } 39 \text { alapján } \\
\text { (régi szabály) }\end{array}$ & rIAS39imp & $\begin{array}{l}\text { IAS39Imp \%-os } \\
\text { aránya a mérlegfö- } \\
\text { összegen belül }\end{array}$ & \multicolumn{2}{|c|}{ 2017.12.31-én. } \\
\hline & \multirow{4}{*}{$\mathrm{ECL}$} & \multirow{4}{*}{$\begin{array}{l}\text { Értékvesztés } \\
\text { IFRS } 9 \text { alapján } \\
\text { (új szabály) }\end{array}$} & \multirow{2}{*}{ rECL } & \multirow{2}{*}{$\begin{array}{l}\text { ECL \%-os aránya a } \\
\text { mérlegföösszegen } \\
\text { belül }\end{array}$} & rECL_201801 & rECL 2018.001.01-én \\
\hline & & & & & rECL_2018q1 & rECL 2018.03.31-én \\
\hline & & & $\mathrm{dECL}$ & ECL \%-os változása & dECL_201801 & $\begin{array}{l}\text { ECL változása } \\
\text { 2017.12.31-röl } \\
\text { 2018.01.01-re } \\
\end{array}$ \\
\hline & & & ULCL & képest & dECL_2018q1 & $\begin{array}{l}\text { ECL változása } \\
\text { 2018.01.01-röl } \\
\text { 2018.03.31-re } \\
\end{array}$ \\
\hline \multirow{3}{*}{ 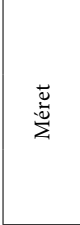 } & \multirow{3}{*}{$\begin{array}{l}\text { Total } \\
\text { Assets }\end{array}$} & & lnTotalAssets & $\begin{array}{l}\text { Mérlegföösszeg } \\
\text { természetes alapú } \\
\text { logaritmusa }\end{array}$ & lnTotalAssets_2017 & $\begin{array}{l}\text { lnTotalAssets } \\
\text { 2017.12.31-én }\end{array}$ \\
\hline & & Mérlegfőösszeg & dTotalAssets & Mérlegföösszeg & dTotalAssets_201801 & $\begin{array}{l}\text { dTotalAssets } \\
\text { 2017.12.31-röl } \\
\text { 2018.01.01-re } \\
\end{array}$ \\
\hline & & & Hivetarnsocts & \%-os változása & dTotalAssets_2018q1 & $\begin{array}{l}\text { dTotalAssets } \\
\text { 2018.01.01-röl } \\
\text { 2018.03.31-re }\end{array}$ \\
\hline
\end{tabular}




\section{2. melléklet}

Változók leíró statisztikái

\begin{tabular}{|l|c|c|c|c|c|}
\hline \multicolumn{1}{|c|}{ Változó } & Átlag & Medián & Variancia & Minimum & Maximum \\
\hline drPrice_18_17 & 0,9871 & 0,9943 & 0,0010 & 0,8700 & 1,0500 \\
\hline drPrice_18q & 0,9928 & 0,9994 & 0,0010 & 0,8600 & 1,0900 \\
\hline drPrice_18q_17 & 0,9688 & 0,9890 & 0,0140 & 0,5100 & 1,3700 \\
\hline rFVTPL_2017 & 0,1087 & 0,0427 & 0,0190 & 0,0000 & 0,7400 \\
\hline rFVTPL_201801 & 0,1127 & 0,0505 & 0,0190 & 0,0000 & 0,7400 \\
\hline rFVTPL_2018q1 & 0,1091 & 0,0385 & 0,0190 & 0,0000 & 0,7300 \\
\hline dFVTPL_201801 & 2,5807 & 1,0068 & 74,8020 & 0,1200 & 76,4400 \\
\hline dFVTPL_2018q1 & 0,9799 & 0,9891 & 0,3580 & 0,0000 & 4,0700 \\
\hline rFVTOCI_2017 & 0,0996 & 0,0891 & 0,0050 & 0,0000 & 0,3300 \\
\hline rFVTOCI_201801 & 0,0889 & 0,0806 & 0,0040 & 0,0000 & 0,2800 \\
\hline rFVTOCI_2018q1 & 0,0888 & 0,0796 & 0,0040 & 0,0000 & 0,3300 \\
\hline dFVTOCI_201801 & 0,9611 & 0,9899 & 0,3040 & 0,0000 & 4,1100 \\
\hline dFVTOCI_2018q1 & 1,5107 & 0,9865 & 14,8620 & 0,0000 & 36,2100 \\
\hline rAC_2017 & 0,7181 & 0,7524 & 0,0250 & 0,2300 & 1,0000 \\
\hline rAC_201801 & 0,7231 & 0,7583 & 0,0240 & 0,1400 & 0,9700 \\
\hline rAC_2018q1 & 0,7243 & 0,7562 & 0,0240 & 0,1100 & 0,9600 \\
\hline dAC_201801 & 1,0125 & 0,9996 & 0,0120 & 0,5900 & 1,4500 \\
\hline dAC_2018q1 & 1,0072 & 1,0027 & 0,0050 & 0,6700 & 1,2100 \\
\hline rECL_201801 & 0,0306 & 0,0148 & 0,0020 & 0,0000 & 0,2400 \\
\hline rECL_2018q1 & 0,0324 & 0,0166 & 0,0020 & 0,0000 & 0,2600 \\
\hline dECL_201801 & 1,1083 & 1,0820 & 0,0710 & 0,1500 & 2,6000 \\
\hline dECL_2018q1 & 1,1059 & 0,9825 & 0,7320 & 0,0100 & 7,4100 \\
\hline lnTotalAssets_2017 & 11,2900 & 11,1752 & 3,2430 & 7,4800 & 14,7400 \\
\hline dTotalAssets_201801 & 1,0000 & 0,9993 & 0,0010 & 0,8700 & 1,2100 \\
\hline dTotalAssets_2018q1 & 1,0067 & 0,9994 & 0,0030 & 0,7800 & 1,1800 \\
\hline
\end{tabular}




\section{HIVATKOZÁSOK}

Ahmed, A. S. - Takeda, C. -Thomas, S. (1999): Bank loan loss provisions: a re-examination of capital management, earnings management and signaling effects. Journal of Accounting and Economics 28, 1-26.

Beatty, A. - Liao, S. (2011): Do delays in expected loss recognition affect banks' willingness to lend? https://doi.org/10.1016/j.jacceco.2011.02.002.

Beaver, W. H. - Eger, C. -Ryan, S. - Wolfson, M. (1989): Financial reporting, supplemental disclosures, and bank share prices. Journal of Accounting Research 27(2), 157-178.

Cantrell, B. W. - McInnis, J. M. - Yust, C. G. (2014): Predicting Credit Losses: Loan Fair Values versus Historical Costs. The Accounting Review 89(1), January, 147-176.

Covas, F. - Nelson, W. (2018): Current Expected Credit Loss: Lessons from 2007-2009. Staff Working Paper 2018-1. Bank Policy Institute.

EL Sood, H. A. (2012): Loan loss provisioning and income smoothing in US banks pre and post the financial crisis. International Review of Financial Analysis 25, December, 64-72.

Fiechter, P. (2011): The Effects of the Fair Value Option under IAS 39 on the Volatility of Bank Earnings. Journal of International Accounting Research 10(1), Spring, 85-108.

Fiechter, P. (2011): Reclassification of Financial Assets under IAS 39: Impact on European Banks' Financial Statements. Accounting in Europe 8(1), 49-67.

Gebhardt, G. - Novotny-Farkas, Z. (2011): Mandatory IFRS Adoption and Accounting Quality of European Banks. Journal of Business Finance and Accounting 38(3-4).

Georgiou, O. - JACK, L. (2011): In pursuit of legitimacy: a history behind fair value accounting. The British Accounting Review 43(1), 311-323.

IAS 39 Financial Instruments: Recognition and Measurement. London: www.ifrs.org.

IFRS 9 Financial Instruments, London; www.ifrs.org.

Kund, A. G. - Rugilo, D. (2018): Does IFRS 9 increase Financial Stability? SSRN Electronic Journal, https://papers.ssrn.com/sol3/papers.cfm?abstract_id=3282509.

LAUX, C. (2012): Financial Instruments, Financial Reporting, and Financial Stability. Accounting and Business Research 42(3), 1-22.

LAux, C. - Leuz, C., (2010): Did fair-value accounting contribute to the financial crisis? Journal of Economic Perspectives 24(1), 93-118.

Lu, Y. - Nikolaev, V. (2019): Expected Loan Loss Provisioning: An Empirical Model. Chicago Booth Research Paper No. 19-11.

O'HANLON, J. (2013): Did loan-loss provisioning by UK banks become less timely after implementation of IAS 39 ? Accounting and Business Research 43(1), 1-34.

Onali, E. - Ginesti, G. (2014): Pre-adoption market reaction to IFRS 9: A cross-country eventstudy. Journal of Accounting and Public Policy 33 (6).

Onali, E. - Ginesti, G. (2015): New Accounting Rules for Loan Loss Provisions in Europe: Much Ado about Nothing? MPRA Paper No. 64266, posted 12 May.

OzILI, P. K. (2019): Impact of IAS 39 reclassification on Income Smoothing by European Banks. University Library of Munich (Germany): MPRA Paper 92098.

PaAnanen, M. - Renders, A. - Shima, K. M. (2012): The amendment of IAS 39: Determinants of reclassification behaviour and capital market consequences. Journal of Accounting, Auditing \& Finance, 27(2), 208-235, https://doi.org/10.1177/0148558X11409151.

WheEler, BARrett (2019) Unrecognized Expected Credit Losses and Bank Share Prices (January 22). Available at SSRN: https://ssrn.com/abstract=3051473

ZHAN, Y. (2013): The effect of reclassification under amendment to IAS 39 on liquidity of bank stocks in the EU. Tilburg University (Germany), http://arno.uvt.nl/show.cgi?fid=129305. 